JINOTEP Vol 8 (2) (2021): 186-193

DOI: $10.17977 /$ um031v8i22021p186

JINOTEP (Jurnal Inovasi Teknologi Pembelajaran)

Kajian dan Riset Dalam Teknologi Pembelajaran

http://journal2.um.ac.id/index.php/jinotep/index

\title{
TEACHERS CHALLENGES IN THE LEARNING PROCESS DURING THE COVID-19 PANDEMIC IN RURAL AREAS
}

\author{
Gabriel Fredi Daar, Ismail Nasar
}

Universitas Katolik Indonesia Santu Paulus Ruteng -Ruteng Flores Indonesia

\section{Article History \\ Received: 12-06-2021 \\ Accepted: 03-07-2021 \\ Published: 04-07-2021 \\ Available online: 03-07- 2021}

\section{Keywords}

learning media; challenges; strategy; teaching

\begin{abstract}
Abstrak
Penelitian ini mengeksplorasi tantangan dan strategi yang diterapkan guru dalam kegiatan belajar mengajar di era pandemi di MAN Ruteng. Penelitian ini merupakan penelitian kualitatif dengan pendekatan fenomenologis. Data diperoleh melalui wawancara, observasi dan dokumentasi. Untuk keperluan wawancara individu, dipilih lima guru secara purposive. Hasil penelitian menunjukkan bahwa media pembelajaran yang digunakan adalah WhatsApp, google classroom, messenger, dan facebook karena dapat digunakan dan diperoleh dengan mudah dan sebagian besar siswa memiliki ponsel. Kemudian tantangan yang dapat diidentifikasi adalah fasilitas penunjang pembelajaran dan lokasi domisili siswa. Sedangkan guru menerapkan strategi praktis aplikatif dalam menangani hambatan kegiatan pembelajaran selama masa pandemic.
\end{abstract}

\section{Abstract}

This study explores the challenges and strategies applied in teaching and learning activities in the pandemic era at MAN Ruteng. This research is qualitative research with a phenomenological approach. Data obtained through interviews, observation, and documentation. For the purposes of individual interviews, five teachers were taken purposively. The results showed that the learning media used were WhatsApp, google classroom, messenger, and Facebook. They are used and obtained easily, and most students have cellphones. Then the challenges that can be identified are learning support facilities and student domicile locations. Meanwhile, teachers apply practical strategies in dealing with barriers to learning activities during the pandemic.
Corresponding author: Ismail Nasar

Adress:Tenda, Manggarai-86518

Instansi:Universitas Katolik Indonesia Santu Paulus Ruteng,

E-mail: nasarismail8@gmail.com
2021 Universitas Negeri Malang p-ISSN 2406-8780 e-ISSN 2654-7953 


\section{INTRODUCTION}

Learning activities during the Covid-19 pandemic experienced challenges that had a significant impact on educational inputs, processes and outcomes. Learning activities that were previously carried out face-to-face were replaced by methods that were almost never done before. Teachers and students are forced to carry out virtual learning activities by utilizing existing technology. Through the use of technology, both teachers and students have the opportunity to learn new things that are developing so fast in today's world of education. In addition, teachers are required to innovate in determining learning techniques and methods so that learning objectives are achieved. By using and integrating technology into the teaching and learning activity both teachers and students experience learning new things. In the context of language learning for instance, technology is helpful to develop verbal skills (Moura \& Carvalho, 2011). This is possible since technologies are completed with features such as multimedia interfaces that help learners learn. Moreover, it's more challenging for teachers because they teach the students who adapt to technology integration quickly. Therefore, students are able to adjust to the use of technology at home though the physical class is closed due to the covid-19 pandemic (Situmorang, Nugroho, \& Pramusita, 2020).

The current state of the Covid-19 pandemic is very worrying. Most schools in Indonesia still carry out learning from home. Teachers who apply online learning by utilizing various learning platforms get a lot of learning experiences and new knowledge. However, there are many teachers living in remote areas with limited resources and facilities cannot carry out learning activities optimally. Several previous studies on learning barriers during the COVID19 pandemic stated that teachers mostly implemented an unaccompanied assignment system. Students come to school to receive assignments from the teacher, and students do those assignments at home. Students come to school the next day to collect the assignment (Mayob, 2020; A. Abidah, et. all.; 2020; Efriana, 2021).

Taking into account the uncertain conditions due to the Covid-19 pandemic, the Indonesian Ministry of Education and Culture issued a decision to implement learning from home for all levels of education in Indonesia. In its implementation, this policy then becomes flexible according to the development of conditions. Some regions are re-implementing face-to-face learning earlier with the main requirements of implementing very strict health protocols and teachers having received vaccinations. The same policy is implemented in schools in Manggarai NTT, including in MAN Ruteng. The schools has applied limited face-toface classroom interaction. Students come to school on different day based on the schedule.

During the covid-19 pandemic,Students face problems related to depression anxiety, poor internet connectivity, and unfavorable study environment at home (Kapasia, et al., 2020). Online learning process takes place in one direction that make it difficultfor students to consult with material needs more explanation (Simamora, 2020).Students lost enthusiasm for learning due to obstacles they experience (Lestiyanawati and Widyantoro, 2020). The students are not ready for the distance education process and there is a lack of application of technology to support distance education training. Moreover, the students do not possess sufficient knowledge and experience about distance education (Sari, 2020).By referring to the problems faced during teaching and learning in the Covid-19 pandemic, rural learners are critical stakeholders in education and in the fight against COVID-19. They cannot be left behind in efforts to fight the pandemic (Dube, 2020). Students are hoped to attain an ability to converse and interact with another person where most of the students face with the conventional method of teaching. They arealso expected to adapt with the new assessment strategy as proposed by the module leader which is for their own beneficial (Mohmmed, et. al., 2020).

It's a great challenge for teachers to cope this problem. These obstacles are more likely to trigger other problems that have an impact on not achieving student learning goals. In reference to this basis, it's necessary to analyze and describe problems teachers face in carrying out learning activities during the civid-19 pandemic and what strategies they use to keep students' learning goals achieved, from the teacher's perspective.

\section{METHOD}

This research was conducted at MAN Ruteng, in April 2021.In order to obtain the objective of the research, it's used qualitative study with phenomenological approach. Data 
188 JINOTEP (Jurnal Inovasi dan Teknologi Pembelajaran) Kajian dan Riset dalam Teknologi Pembelajaran Vol. 8, No. 2, Juli 2021, Hal. 186-193

were obtained through interview, observation and documentation. For the purpose of individual interview, five teachers taken purposevely based on the following criteria:

a. Respondents have more knowledge and understanding on the issues encountered in teaching and learning activity during covid19 pandemic.

b. Respondents are actively undertaking teaching and learning activity during covid19 pandemic.

c. Respondents are willing to participate in the interview.

The technique of data analysis was undertaken using a qualitative description, and to describe the systematic, factual, and accurate data, inductive description is applied by implementing the model of analysis proposed by Miles and Haberman (1994) consisting of data collection, data reduction, data display, and conclusion.

\section{RESULTS}

In order to obtain the data for the purpose of answering research problem, some guideline questions were used by the researchers during the interview process. They were used to elaborate teachers' problems and strategy used in the teaching and learning activity during covid-19 pandemic. It's used some indicators that performed in teaching and learning activity included media and learning sources used in teaching and learning activity, problems that hinders teaching and learning activity, strategy undertaken and teachers' recommendations.

\section{Media and learning sources}

In order to answer the research question dealing with learning media and learning sources, the researchers proposed the question "What media do you use to deliver teaching materials to your students?". Based on the interview it's found that teachers use whats app, google classroom, messanger, and facebook in the teaching and learning process. Teachers use such kind of media since they are used and obtained easily by both teachers and students.

"I usually use whats app, google classroom, messanger, and facebook to deliver the materials to my students. Most students possess mobile phone, though some don 't (RN)'". Some more reasons for using such kinds of learning media since most students possess mobile phone that can be used to access WA, google classroom and facebook easily, and most students are familiar with them.

Dealing with learning sources, the subject said that students mostly used internet, workbooks and handout. During this covid-19 pandemic, students are encouraged to use digital technology as it's an effective learning source in finding the materials learnt.

"Internet, workbook and handout are the common learning sources that our students use during covid-19. Due to covid-19, we give students handout and workbook and they study and do assignments at home (RN) “.

\section{Challenges teachers found in the teaching and learning activity}

In identifying challenges, the researchers proposed the question "What are the challenges you encounter in the teaching and learning activity in the Covid-19 pandemic?". Based on the interview and observation, it's found that 1) Learning support facilities. There are many students who do not have learning media such as android mobile phone or laptop. 2) Some students live in the area with no internet networking.

"We face many problems in the teaching and learning process during this covid-19 pandemic. We can not undertake teaching and learning process effectively since some students don't possess mobile phones as the main media used to obtain information from teachers. Some others live in the area with no internet access" $(D S)$.

Other identified problem is the availability of internet connection provided by school. It is found that schoolprovides internet network for teachers and students to access and obtain information. However, the available internet connection doesn't fulfill the learning needs for all teachers and students.

"The most problem that we find in applying online learning during covid-19 pandemic is the capacity of internet networking. Our school even doesn't provide sufficient internet capacity for teachers and students" $(I H)$. Teachers Strategy in the Teaching and learning Process

Teachers' teaching strategy determines the success of teaching and learning activity in the pandemic. In order to obtain information about teachers' strategy, the researchers proposed the question "What is your strategy to minimize the problems found in order that 
teaching and learning process keep going and learning objectives achieved?". Based on the interview, it's found some practical and applicative strategies undergone by teachers such as asking or inviting students who don't possess learning devices such as android mobile phones to come to school to take the assignments.

"I ask the students to come to school to take the printed assignments while applying strict health protocol. This is for the students who don't have mobile phone or internet data" (RN).

Students are provided some exercises that should be accomplished within certain limit of time. They do those exercises at home under parents' supervision and guide. Other strategy is asking students to stay in the place where internet connection is available. Students also were asked to use the most common media such as messanger or facebook.

"I usually ask the students to stay at the place where internet connection is available. And I ask the students who don't have mobile phone to use the common media such as messanger" (FR).

At certain situation, teachers provide longer time for students to accomplish certain assignments. It helps them obtain more chance to do more task and get more information through exercise they do.

\section{DISCUSSIONS}

\section{Media and Learning Sources}

Learning media is a vital component that should be taken into account in the teaching and learning activity. The position of learning media becomes important since it determines whether the subject matter can be delivered maximally or not. If the more concrete learning media is used, the message (information) in the learning process delivered by the teacher to students would be better. However, if the more abstract learning media is used, the message (information) would be difficult to accept by the students. Students find difficulty in understanding and absorbing what the teacher delivers (Suryani, 2016). Moreover Puspitarini and Hanif (2019) through their study identified that learning media becomes another alternative in the learning process which is used to improve students' learning motivation. Learning media helps learners understand the subject matter and have encouragement to learn more the material being learnt. Teacher who uses appropriate learning media in accordance with learning objectives is considered to be able to achieve the students learning objectives. Based on the study, it's found that there are some learning media used by teachers to deliver materials to the students such as WA, google classroom, messanger, and facebook. Teachers use such kind of media since they are used and obtained easily by both teachers and students. Some more reasons for using such kinds of learning media since most students possess mobile phone that can be used to access WA, google classroom and facebook easily, and most students are familiar with them. The finding is in line with a study conducted by Mahyoob (2020). He identified learning media commonly used by the students in the teaching and learning activity during covid-19 pandemic, and the most common media was WhatsApp platform. Mobile phones helped online learning succeed because most students used their mobile phones in this context. Other study also identified that Google Classroom is the common media that the students use in the teaching and learning process (Ningsih, 2020; Surahman, 2020; Setiawan, \& Iasha, 2020)

Digital technology plays an important role in the teaching and learning activity during covid-19 pandemic. Technology is an alternative to solve the problems in making education institution keep conducting teaching and learning activity. It even can be assumed that the activity of teaching and learning depends on the presence of digital technology as the media for delivering the materials. Even though some studies revealed that the limitation of technology becomes a burden for both teachers and students, however the presence of technology can help teachers and students avoided from the risk of covid-19 spread (Lestinawati, 2020; Situmorang, Nugroho, \& Pramusita, 2020).

Other determinant factor for the success of teaching and learning activity in the covid-19 pandemic is the presence of learning sources. Based on the study it's found that learning sources used in the teaching and learning process are internet, workbook, and handout. Internet becomes the most and mainly learning sources since it's easily accessed as long as the students have android mobile phone and internet data. However, it's not for the students who don't 
possess android mobile phone or those who live in areas with no access to internet connection. They used work book or hand out. The study also highlighted that teachers ask the students to come to school to take the assignments. It's conducted to replace the activity of teaching and learning. For certain reason, it's a better way for students to get direct feedback of the assignments that have been submitted as long as health protocol is applied.

\section{Challenges teachers found in the teaching and learning activity}

Some studies have revealed that the emergence of covid-19 pandemic affects problems in many sectors of human lives including education (Mahyoob, 2020; Ria, 2020; Efriana, 2021). The present study aims to identify challenges in the teaching and learning activity during covid-19 pandemic from teachers' perspectives. Based on the interview, it's found some challenges; 1) Learning support facilities. There are many students who do not have learning media such as android mobile phone or laptop. Moreover, school doesn't provide internet network for students to access and obtain information. 2) Some students live in the area with no internet networking.Syahria (2020) through her study showed that teachers experienced challenge regarding the weak infrastructure. Both teachers and students complained about the unstable connections of the internet. There was a blackout in their area often, which caused most of the students to submit the assignments late. Efriana (2020) also identified that some students do not have devices such as gadgets or computers as online learning media. Some other students borrow their parents' devices to study online. Another student sometimes gets a turn to use the device after his parent goes home from work. Efriana also identified that a number of students live in areas that do not have internet access. They cannot receive lesson materials and assignments delivered by teachers via the internet network. To cope with this problem, students are asked to come to school to take the assignments in order that they can accomplish it at home. The assignments are submitted a few days later after being completed. Stenman, S., \& Pettersson, F. (2020) suggested that it's a need for remote teaching to expands the learning environment. Students are provided with equal access to qualified teachers and a wider range of learning solutions for different needs. To deal with it, preservice teachers should be supported during professional experience to promote teaching in rural area. It's a way to overcome teacher shortages (Hudson, Young, Thiele, \& Hudson, 2020; Thaariq, Surahman, Murti, Faqiroh, \& Kusworo, 2020). Pokhrel and Chhetri (2021) stated that the issue of Internet connection and access to digital devices becomes the substantial issues of many countries. In developing countries, children are not able to afford online learning devices due to the economically backward. Moreover the online education poses a risk of exposure to increased screen time for the learner. Thus, the alternative way is to engage students with offline learning activities and self directed learning implementation. However, it becomes more challenging for the students without parents guide.

The use of technology is inevitable and inseparable in the teaching and learning activities during this COVID-19. Both teachers and students depend on the use of technology to keep teaching and learning going (Situmorang, Nugroho \& Pramusita, 2020). Technology becomes a crucial component that can't be neglected. It can be assumed that the absence of digital technology affects the absence of teaching and learning activity. The study also identified that the problems become more complex because some students live in the area where internet networking is unavailable. This finding actually has been revealed by some previous researches. Pokhre and Chhetri (2020) found that during online learning, students who live in rural areas with their parents are mostly illiterate farmers engage students with farming activities that can disturb their learning process. Even certain students asked to postpone exam time towards the afternoon since they had to work on the fields during morning hours. To this extend, it's teachers task to search for effective strategy in order that students implement independent learning optimally. Parents are as well encouraged to be aware of their role as educators at home to supervise and guide their children in utilizing self learning.

Teachers Strategy in the Teaching and learning Process

Teaching strategy is useful to reduce the effect of obstacles found in the teaching and learning activity during covid-19 pandemic. Teachers' strategy implementation determines whether teaching and learning process can be undertaken or not. Moreover, teacher strategy 
affects students understanding on the materials being learnt. The present study tries to identify teachers' strategy in handling problems they encounter in the teaching and learning activity, and based on the interview it's found that there are some applicative strategies applied by teacher that is considered helpful in tackling the problems they face in the teaching and learning process. First, asking or inviting students who don't possess learning devices such as android mobile phones to come to school to take the assignments. Moreover, students are provided some exercises that should be accomplished within certain limit of time. They do those exercises at home under parents' supervision and guide. This strategy is undertaken to keep teaching and learning going. By doing so, students are forced to utilize independent learning while obtaining feedback when coming back to school to submit the completed assignments. Sukmono (2015) through his study on the implementation of Self Directed Learning in learning Bahasa Indonesian stated that the use of the SDL (Self Directed Learning) in learning bahasa Indonesian applies an independent learning system. This independent learning system can develop students actively. Active learning will make students better understand the material they get. Humaira and Hurriyah (2018) through their study on Students' Perspectives towards Self-Directed Learning out of Classroom showed that the students have difficulties in choosing appropriate learning strategy, doing self-assessment and conducting self-reflection. Therefore, promoting selfdirected learning instruction is needed for successful learning. The teaching and learning activity during covid-19 pandemic is mostly undertaken out of classroom. It can be said that one of the advantages of the emergence of covid19 is the improvement of students' opportunity to implement self directed learning. Students who are involved in the independent learning obtain more opportunity to develop knowledge and skills related to the subject being learnt. Second, students were asked to stay in the place where internet connection is available. Students also were asked to use the most common media such as messanger or facebook. To this extend, Sutarto, Sari \& Fathurrochman (2020) mentioned that choosing simple and attractive learning media as the strategy to make the students learn in the covid-19 pandemic. Media were simple in terms of affordable costs, easy to use by teachers and students in the learning process. Other strategy is giving compensation e.g. extending the duration of task submission to students who don't possess mobile phone.

Bullen and Jones (2007) as cited in Syahria (2020) proposed collaborative teaching strategy to cope with the difficulties in learning and teaching. In applying collaborative teaching strategy, teacher and students and students themselves cooperate in accomplishing certain task in the teaching and learning with the help of various modern web tools for communication and online teamwork, such as Zoom and WhatsApp chat and video. If it refers to collaborative teaching strategy as proposed by Bullen and Jones (2007), teachers at MAN Ruteng didn't utilize the strategies that encourage students to actively participate in an online teamwork. Students weren't forced to adapt the learning technology development due to many challenges experienced by teachers, students and parents.

\section{Teachers' Recommendation}

Teachers' recommendations are useful in the effort to overcome the obstacles found and maximize the implementation of strategies which are considered to help both teachers and students achieve learning objectives in the covid-19 pandemic. During the interview, the researchers obtained teachers' recommendation as follows: 1) Parents should support their children in applying distance learning. It's applied through providing the android mobile phone as the common media used in the teaching and learning process during covid-19 pandemic. Moreover, parents should supervise and guide the implementation of self learning at home. 2) Technology is the main media used by both teachers and students in undertaking teaching and learning process. Thus, school authorities should extend and develop the capacity of school internet. It can help both teachers and students minimize the teaching and learning cost in the pandemic period.Olaitan (2020) through his study identified similarrecommendation dealing with technological problems in the teaching during covid-19 pandemic. The government is hoped to be prepared to adopt the paradigm without any political biasby providing adequate fund to strengthen and develop the technological infrastructure to support online learning. Moreover, it's expected that there is sufficient time allotted before accepting any technological means of imparting education in order that both the learnt and the learner are on the same 
192 JINOTEP (Jurnal Inovasi dan Teknologi Pembelajaran) Kajian dan Riset dalam Teknologi Pembelajaran Vol. 8, No. 2, Juli 2021, Hal. 186-193

frequency as far as the process is concerned (Gokuladas and Sam, 2020).

\section{CONCLUSION}

The emergence of covid-19 pandemic brings an impact on teaching and learning activities. Teachers as educators find problems in managing teaching and learning process which mostly occurs outside classroom. However, teachers are demanded to take an effort to find and use strategies in order that obstacles in teaching and learning due to covid19 can be reduced and learning objectives are achieved. Based on the findings, it can be concluded that 1) learning media used that can be identified are WA, google classroom, messanger, and facebook. Teachers use such kind of media since they are used and obtained easily by both teachers and students. 2) The challenges that can be identified are learning support facilities. There are many students who don't possess learning media such as android mobile phone or laptop. Moreover, school doesn't provide internet network for students to access and obtain information. Some students live in the area with no internet networking. 3) The strategies applied by teachers are asking or inviting students who don't possess learning devices such as android mobile phones to school to take the assignments. Moreover, students are provided some exercises that should be accomplished within certain limit of time. Students were asked to stay in place where internet networking is available. Students also were asked to use the most common media such as messanger or facebook. Other strategy is giving compensation e.g. extending the duration of task submission to students who don't possess mobile phone.

\section{REFERENCES}

Abidah, A., Hidaayatullaah, H. N., Simamora, R. M., Fehabutar, D., \& Mutakinati, L. (2020). The impact of covid-19 to indonesian education and its relation to the philosophy of "merdeka belajar". Studies in Philosophy of Science and Education, 1(1), 38-49.

Dube, B. (2020). Rural online learning in the context of COVID 19 in South Africa: Evoking an inclusive education approach. Multidisciplinary Journal of Educational Research, 10(2), 135-157. doi: 10.4471/remie. 2020.5607

Efriana, Leli. (2020). Problems of Online
Learning during Covid-19 Pandemic in EFL Classroom and the Solution. JELITA: Journal of English Language Teaching and Literature. Volume 2, Number 1, pages 38-47

Hudson, S., Young, K., Thiele, C., \& Hudson, P. (2020). An exploration of preservice teachers' readiness for teaching in rural and remote schools. Australian and International Journal of Rural Education, 30(3), 51-68.

Humaira, S. A., \& Hurriyah, I. A. (2017, August). Students' Perspectives towards Self-Directed Learning out of Classroom. In International Conference on English Language Teaching (ICONELT 2017) (pp. 6-11). Atlantis Press.

Kapasia, N., Paul, P., Roy, A., Saha, J., Zaveri, A., Mallick, R. \& Chouhan, P. (2020). Impact of lockdown on learning status of undergraduate and postgraduate students during COVID-19 pandemic in West Bengal, India. Children and Youth Services Review, 116, 105194.

Lestiyanawati, R. (2020). The Strategies and Problems Faced by Indonesian Teachers in Conducting e-learning during COVID-19 Outbreak. CLLiENT (Culture, Literature, Linguistics, and English Teaching), 2(1), 7182.

Mahyoob, M. (2020). Challenges of e-Learning during the COVID-19 Pandemic Experienced by EFL Learners. Arab World English Journal (AWEJ), 11(4). 351-362 DOI:https://dx.doi.org/10.24093/awej/vol11n 04.23

Mohmmed, A. O., Khidhir, B. A., Nazeer, A., \& Vijayan, V. J. (2020). Emergency remote teaching during Coronavirus pandemic: the current trend and future directive at Middle East College Oman. Innovative Infrastructure Solutions, 5(3), 1-11.

Moura, A., \& Carvalho, A. (2011). Aprendizagem mediada por tecnologias móveis: novos desafios para as práticas educativas. In P. Dias e A. Osório (Eds.), Actas da VII Conferência Internacional de TIC na Educação Challenges, Braga: Universidade do Minho (233-246).

Ningsih, S. (2020). Persepsi Mahasiswa Terhadap Pembelajaran Daring Pada Masa Pandemi Covid-19. JINOTEP (Jurnal Inovasi Dan Teknologi Pembelajaran): Kajian Dan Riset Dalam Teknologi Pembelajaran, 7(2), 124132.

Olaitan, Bolaji Sefiu. (2020). Challenges Of Integrating Mobile Technologies Into Teaching And Learning Process In Nigerian Primary Schools During Covid-19 Pandemic. Trailblazer International Journal Of Educational Research. Volume 1, Number 1, 61-67 
Pokhrel, S., \& Chhetri, R. (2021). A literature review on impact of COVID-19 pandemic on teaching and learning. Higher Education for the Future, 8(1), 133-141. DOI: $10.1177 / 2347631120983481$.

Puspitarini, Y. D., \& Hanif, M. (2019). Using Learning Media to Increase Learning Motivation in Elementary School. Anatolian Journal of Education, 4(2), 53-60.

Sari, T., \& Nayır, F. (2020). Challenges in distance education during the (Covid-19) pandemic period. Qualitative Research in Education, 9(3), 328-360. doi:10.17583/qre.2020.5872.

Ria, N. S. (2021). Teaching during covid-19 pandemic: what should educators do to save nations'educational crisis?. Lectio: Journal of Language and Language Teaching, 1(1), 2940.

Setiawan, B., \& Iasha, V. (2020). Covid-19 Pandemic: The Influence Of Full-Online Learning For Elementary School In Rural Areas. JPsd (Jurnal Pendidikan Sekolah Dasar), 6(2), 114-123.

Situmorang, K., Nugroho, D. Y., \& Pramusita, S. M. (2020). English Teachers' Preparedness in Technology Enhanced Language Learning During Covid-19 Pandemic-Students' Voice. Jo-ELT (Journal of English Language Teaching) Fakultas Pendidikan Bahasa \& Seni Prodi Pendidikan Bahasa Inggris IKIP, 7(2), 57-67.

Simamora, R. M. (2020). The Challenges of online learning during the COVID-19 pandemic: An essay analysis of performing arts education students. Studies in Learning and Teaching, 1(2), 86-103.
Suryani, N. (2016). Utilization of Digital Media to Improve The Quality and Attractiveness of The Teaching of History. In Proceeding of the International Conference on Teacher Training and Education (Vol. 2, No. 1, pp. 131-144).

Surahman, E. (2020, October). Student Satisfaction toward Quality of Online Learning in Indonesian Higher Education During the Covid-19 Pandemic. In 2020 6th International Conference on Education and Technology (ICET) (pp. 120-125). IEEE.

Sukmono, Nur Dwi. (2015). Metode Pembelajaran Self Directed Learning Berbasis Ict DenganPemanfaatan Game Android Berkarakter Untuk Pembelajaran Bahasa Indonesia. Seminar Nasional Pendidikan Bahasa Indonesia.

Sutarto, Sutarto, Dewi Purnama Sari, and Irwan Fathurrochman. (2020). Teacher strategies inonline learning to increase students' interest in learning during COVID-19 pandemic. Jurnal Konseling dan Pendidikan. Vol. 8, No.3, 2020, pp. 129-137.

Stenman, S., \& Pettersson, F. (2020). Remote teaching for equal and inclusive education in rural areas? An analysis of teachers' perspectives on remote teaching. The international journal of information and learning technology.

Thaariq, Z. Z. A., Surahman, E., Murti, S. A., Faqiroh, B. Z., \& Kusworo, N. R. (2020, December). Analysis of Learners Characteristics and Learning Process Preferences during Online Learning. In 1st International Conference on Information Technology and Education (ICITE 2020) (pp. 49-54). Atlantis Press. 